\title{
Quebec's Public Health EThics Committee: A Model for the Public Health Agency of Canada?
}

\author{
Mireille LaCroiX
}

The federal government of Canada has recently underlaken to modernize its public health infrastructure. including setting up the Public Heallh Agency of Canada (Agency). The structure and organizational features of this Agency are still being determined, however. Afier a brief discussion of public health ethics, this article examines Quebec's Comite d'éthique de santé publique (CESP) in detail and proposes the CESP as a model for the new federal Agency. The author explores the role of the CESP in public health activities and programs. She discusses the membership and transparency of the CESP and also cririques its circumscribed mandate. with the view of examining whether Quebec 's CESP could serve as a model for the newer federal Agency.
Le gouvernement fédéral du Canada vient d'entreprendre la modernisation de l'infrastructure de la santé publique, y compris celle de l'Agence de santé publique du Canada (Agence). La structure et les caractéristiques organisationnelles de cette agence ne sont cependant pas encore définies. Apres une brève discussion sur l'éthique de la samté publique, cet article examine le Comité d'éthique de santé publique (CESP) du Québec en détail, et propose le CESP en tant que modele d'une nouvelle agence fédérale. $L$ auteur explore le rôle du CESP dans les activités et programmes de santé publique. Elle discute des membres et de la transparence du $C{ }^{P}$ ef fait la critique de son mandat circonscrit dans le bur d' examiner si le CESP du Québec pourrait servir de modèle pour une nouvelle agence fédérale.

\section{TABLE OF CONTENTS}

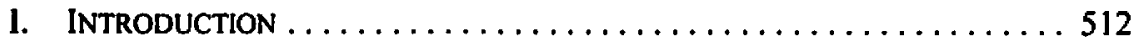

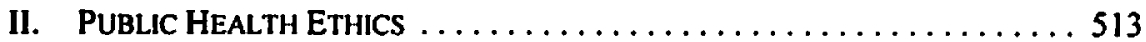

III. QUEBEC'S PUBLIC HEALTH ACT .................... 514

A. TWO DEFINITIONS OF PUBLIC

HEAlth SurvellLancE .................... 515

B. Public Health Surveillance Plans

and Data Collection ....................... 516

IV. THE CREATION OF THE COMItÉ D'ÉthIQUE de SANTÉ PUBLIQUE $\ldots \ldots \ldots 518$

V. THE MANDATE OF THE COMTTÉ D'ÉTHIQUE dE SANTÉ PUBLIQUE $\ldots \ldots .519$

VI. ORganization OF THE COMITÉ D'ÉthIQUE de SANTÉ PUBLIQUE $\ldots \ldots \ldots 522$

VII. THE APPROACH OF THE COMITÉ D'ÉTHIQUE

DE SANTÉ PUBLIQUE ......................... 524

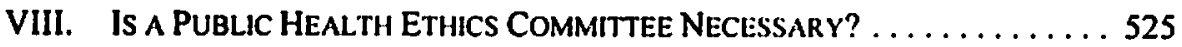

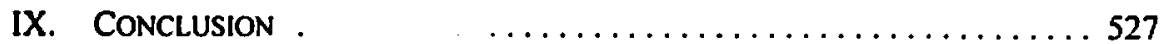

LL.M., Research Associate, Centre de recherche en droit public, Université de Montréal. I wish to thank Bartha Maria Knoppers for her continued guidance and encouragement, Gabrielle Gregoire for her valuable assistance with research, as well as Daniel Weinstock, President of the CESP. France Filiatrault of the CESP Secretariat and Dr. Riclaard Masse, CEO if the Institut national de santé publique du Québec for generously agreeing to mect with me and share valuable practical information about the committee and the Quebec public health system. This research was conducled under the umbrella of the Legal Foundations for a National Disease Control and Surveillance Agency in Canada and was supported by a grant from the Population and Public Health Research Institute. Canadian Institutes of Health Research.

The committee's official name is the "Comité d'éthique de santé publique." The author has taken the liberty to translate the name for ease of comprehension. 


\section{INTRODUCTION}

During the latter half of the twentieth century, as infectious diseases receded and advancements in clinical medicine captured the public's imagination, the role of public health was overshadowed by fascinating interventions such as open heart surgery, organ transplants, dialysis, joint replacement surgery and in vilro fertilization. Antibiotics and vaccines had greatly diminished the incidence and impact of infectious diseases to the extent that these were no longer seen as a serious threat.' However, during the past decade, a number of crises brought public health to the forefront once more. The contaminated blood scandal, the emergence of multi-drug resistant tuberculosis, the contamination of the water supply in Walkerton, Ontario and North Battleford, Saskatchewan, tainted meat scares, and the emergence of new diseases such as West Nile virus, SARS and more recently, the avian flu, have reminded the Canadian public of the threat posed by infections and other forms of contamination. ${ }^{2}$ Because it received extended media coverage, the SARS outbreak in particular prompted questions about the capacity of public health services to manage these crises and to prevent them in the future. Various committees and commissions were mandated to review the events and to make recommendations for addressing the shortcomings of Canada's public health systems. ${ }^{3}$ In light of these recommendations, the federal government has taken steps to renew its health protection legislation and to modernize its public health infrastructure. One of these steps was the creation of the Public Health Agency of Canada.

However, beyond the shortcomings of the public health system that came to light during the SARS outbreak (the shortage of resources and qualified personnel; insufficient preparation and planning; inadequate organizational structures; lack of integration between health protection and clinical care services; organizational culture issues; and inadequate collaboration and communication between actors), ${ }^{4}$ what also became obvious was that a host of legal and ethical issues arose out of the public health interventions undertaken to control the outbreak." The question therefore arises; how can the new Public Health Agency of Canada ensure that it has mechanisms in place to adequately address the ethical issues that

1 Health Canada, National Advisory Committec on SARS and Public Health, Learning From SARS: Renewal of Public Heallh in Cansda (Ontawa: Health (anida, 2003) al 45-47 (Chair: David Naylor) [Learning From SARS].

: C. Colin, "La santé publique au Qucbecc à l'aube du XXI" siccle" (2004) 16 Santé publique 185 at 186. See also Daniel Callahan \& Bruce Jennings. "Ethics and Public Health: Forging a Strong Relationship" (2002) 92 American Journal of Public Health 169.

Learning From SARS. supra nole I: Commission to Investigate the Introduction and Spread of SARS in Ontario, Interim Report: SARS and Public Health in Ontario (Toronto: Queen's Printer, 2004) (Commissioner: Archie Camphell), online: Ontario Ministry of Health and Long Term Care <www. health.gov.on.ca/english/public/pub/ministry_reports/campbell04/campbell04.pdi> [Campbell Report]; Commission to Investigate the Introduction and Spread of SARS in Ontario, Second Interim Report: SARS and Public Healih legislation (Toronto: Queen's Printer, 2005) (Commissioner: Archic CampbelI), online: SARS Commission <www.sarscommission.ca/report/nterim_2.htm|> [Second Interim Campbell Report]: Canada. Standing Senate Committee on Social AfTairs. Science and Technology. Reforming llealth Protection and Promotion in Canada: Time ro Act (Ottawa: Senate of Canada, 2003) (Chair: Michael J.L. Kirby) (Time to Act).

Time to $\mathrm{Act}$, ibid. at II.

Lawrence O. Gostin, Ronald Bayer \& Amy L. Fairchild, “Lthical and Legal Challenges Posed by Severe Acute Respiratory Syndrome: Implications for the Control of Severe Infectious Disease Threats" (2003) 290 JAMA 3229 
will derive from its policies, programs and interventions? What type of mechanism or procedure would be appropriate? This article examines one potential model for systematic ethics review of public health activities: Quebec's "Comité d'éthique de santé publique" (the public health ethics committee, the CESP). Before discussing the committee itself, J begin with a discussion of public health ethics, followed by a brief overview of the Qubec Public Health Act and of the context in which the CESP was created. I then turn to the public health ethics committee - its creation, its mandate, its organization and its approach. I end with a discussion of the questions of whether and how it could serve as a model for the Public Health Agency of Canada.

\section{I1. Public Health Ethics}

Public health ethics can be defined as "the principles and values that help guide actions designed to promote health and prevent injury and disease in the population." This field of inquiry is relatively new (particularly in comparison to traditional biomedical ethics), but has drawn attention from scholars and policy makers in the recent years. ${ }^{7}$ Whereas traditional biomedical ethics uses a patient-centred approach and locuses on individual interests and the duties of single health professionals, public health ethics is principally concerned with community interests and collective values. The foundations of public health rest on respect for the common good, the pursuit of healthy living, beneficence (i.e. acting for the benefit of the population) and paternalism. Its interventions are justified, and circumscribed, by values of solidarity, responsibility, non-maleficence, fairness, social justice and utility, as well as respect for privacy, autonomy and personal integrity. ${ }^{8}$ Public health interventions often place limits on individual rights or freedoms, for example: privacy when the reporting of personal information is mandatory; bodily integrity when immunization, testing or treatment are imposed; moving about when one is placed in quarantine or isolation; and autonomy, through sanitary regulations and health and safety standards. This is justified in the interest of benefiting population health. The task of public health ethics is to provide guidance for balancing communal interests and individual interests in order to maximize social good.

Though ethics constitutes an inherent element of public health practice, few comments exist regarding comprehensive frameworks for the analysis of ethical aspects of public health practice, ${ }^{9}$ and few jurisdictions seem to have adopted mechanisms or organizational tools to guide public health planning and interventions. The American Public Health Association's

" Lawrence O. Gostin, "Tradition, Profession. and Values in Public llealtli" in Bruce Jennings ef al. . eds. . Ethics and Public Heallh: Model Curriculum (Washington: Health Resources and Services Administration. 2003) 13 at 14, online: Association of Schools of Public llealth <www.asph.org/ document.cfm?page $=782>$.

- Nancy E. Kass. "Public Itealth Ethics: From Foundations and Frameworks to Justice and Global Public Heallh" (2004) 32 J. I.. Med. \& Ethics 232. For examples of discussions of public health ethics, see Marc J. Roberts \& Michatel R. Reich. "Ethical analysis in public healtli" (2002) 350 The Lancel 1055 : James F. Childress ef al. "I"ublic Health Lithics: Mapping the Terrain" (2002) $32 \mathrm{~J} \mathrm{~L} \mathrm{Med} \mathrm{\&} \mathrm{Elhics}$ 170; Callahan \& Jennings, supra note 2.

Raymond Massé. Ehique el samé puhlique: Enjeux, valeurs ef normatume (Siant-Nicolas, Quc Presses de l'Université l.aval, 2003) at I1I-12; Kass, stipra note 7 at 235.

" Three recent articles by bioctlicists propose frameworks: (hildress et al. supra nole 7; Nancy E. Kass. "An Ethics Framework for Public Healli" (2001) 91 American Journal of Public Ilealth 1776; James F. Childress \& Ruth Gaare Bernheim, "Beyond the Liberal and Communitarian Impasse: A Framework and Vision for Public Health" (2003) 55 Fla. L. Rev. 1191 
Public Health Code of Ethics sets out principles and values for the practice of public health, but it falls short of offering an approach for weighing these principles, stating that "[t]here is no ethical principle that can provide a solution to [the] perennial tension in public health" between individual interests and community good. ${ }^{10} \mathrm{~A}$ survey of public health legislation from various jurisdictions in Europe and North America, as well as Australia and New Zealand, reveals that few formal ethics review processes for public health interventions exist. Countries such as France, Belgium and Switzerland have created central advisory committees on bioethics or on medical ethics, but their mandates encompass general ethical issues relating principally to the practice of medicine and/or clinical research." The mandate of France's National Consultative Bioethics Committee does include public health issues. ${ }^{12}$ The committee has occasionally provided opinions in the past on issues such as prevention of HIV infection, ${ }^{13}$ HIV screening ${ }^{14}$ and information regarding risk of transmission of Creutzfeldt-Jakob disease through blood, ${ }^{\text {15 }}$ but that has not been its primary focus. The province of Quebec, on the other hand, has created a specific mechanism for the ethical analysis of proposed public health interventions. Though the experience of the public health ethics committee is limited due to its short history and its circumscribed mandate, it is a potentially interesting model of systematic review of surveillance activities.

\section{QUEBEC'S PUBLIC HEALTH ACT'16}

During the 1990s, it became clear to public health professionals and to the government of Quebec, that the public health legislation in effect at the time (the Public Health Protection

American Public Health Association, Public Meallh Code of Elhics, online: American Public Health Association <www.apha.org/codeofethics/ethics.htm>. For a discussion of the Code of Elhics, see James C. Thomas et al,, "A Code of Ethics for Public Health" (2002) 92 American Journal of Public Health 1057.

Loi $n^{\circ} 2004-800$ du 6 aoút 2004, art. I, J.O., 7 August 2004, 14040; Décret $n^{\circ} 2005-390$ du 28 avril 2005, art. 1, J.O., 29 April 2005, 7428 (France); Ordonnance sur la Commission nationale d'éthique dans le domaine de la médecine humaine, 814.903 (4 December 2000) (Switzerland); Comité consultatif de Bioćthique de Belgique, online: Federal Government of Belgium <www. health.fgov. be/bioeth/fr/index-fr.htm>.

The committec's mandate is to provide opinions on ethical and social issues raised by progress in the areas of biology, medicine and health. It can be mandated by the French President, the President of the National Assembly, the President of the Senate, or a member of government, as well as an academic institution, a public instilution or a foundation whose principal activities are research, technological development or health protection and promotion, to provide an opinion on a specific issue. Individuals who are members of the organizations listed can also request an opinion from the committee. Loi $n^{\circ}$ 2004-800 du 6 aoùt 2004, ibid: Décret $n^{\prime \prime} 2005-390$ du 28 avril 2005, ibid.

France, National Consultative Bioethics Committec, Opinion on ethical problems raised by action to combat the spread of infection by the human immunodeficiency virus (HIV), Report No. 14 (Paris: CCNE, 1988).

France, National Consultative Bioethics Committec, Opinion on screening for infection by the AIDS virus, Report No. 31 (Paris: CCNE, 1992).

France, National Consultative Bioethies Committec, Information regarding the risk of blood iransmission of Creuzzeldt-Jakob disease, Report No. 85 (Paris: CCNE, 2004).

16 R.S.Q., c. S-2.2 [Act]. The stalute was adopted on 19 December 2001 : Quebec, Assemble nationale, Journal des débats 34:74 (19 December 2001) at 4841-43. For a more complete discussion of the Public Mealth Act and the Quebec public health system, see Mireille Lacroix, "The Quebec Public Health System: A Modem Model" in Tracey Bailey, Timothy Caulfield \& Nola Ries, cds., Public Health Laiv and Policy (Toronto: Butterworths, 2005) 497. 
$A C t$ of 1972) $)^{17}$ was no longer adequate. ${ }^{18}$ The social and legal landscape had changed significantly following the adoption of that statute: a new Civil Code ${ }^{19}$ had been adopted along with personal information protection legislation; the focus of public health had shifted to include health promotion; ${ }^{20}$ ethical standards had evolved substantially; and many social changes had occurred. ${ }^{21}$ The Public Health Protection Act was therefore obsolete and the provincial government undertook the long process of developing a modernized legislative framework that would meet current needs and that would facilitate a proactive approach. This led to the adoption of the Public Health $\mathrm{Act}^{22}$ in late 2001 and to the creation of new institutions whose mandate is to support the Minister of Health and Social Services and the province's public health directors in their functions. One of these institutions is the CESP.

The Act is based on a broad definition of public health, one that encompasses not only health protection, but also the promotion of population health and well-being ${ }^{23}$ through interventions aimed at improving social determinants of health. ${ }^{24}$ In order to meet these objectives, the $A c t$ identifies four core functions of public health that are the basis of the duties and powers it sets out: (1) ongoing surveillance of the population's health status; (2) the promotion of health and well-being; (3) the prevention of diseases, injuries and psychosocial problems that can have an impact on population health; and (4) health protection. ${ }^{2 s}$ With the exception of surveillance, these functions are generally similar to those identified in public health literature and reports from other jurisdictions. ${ }^{26}$

\section{A. Two Definitions of Public Healti Surveil.lance}

In Europe and North America, surveillance is generally defined as the ongoing systematic collection and analysis of public health data, as well as its interpretation, and its

R.S.Q., c. P-35 (repealed I April 2002).

Québec, Commission permanente des affaires sociales, Journal des débats 37:26 (18 September 2001) at 1-5 (M. Rémy Trudel, M. Richard Massé); Québec, Assemblée nationale, Journal des débats 37:60 (22 November 2001) 3842-53; Québec, Commission permanente des affaires sociales, Journal des débats 37:38 (27 November 2001) at 1-2 (M. Rímy Trudel). Hereinafter, the Journal des débats will be referred to as J.D.

The Civil Code of Québec. C.C.Q. replaced the Civil Code of Lower Canada.

The Public Health Protection ACt, supra note 17, contained no provisions with regard to health promotion or surveillance; there was therefore no legal framework for these interventions. even though they were part of public health practice.

Supra note 18.

Supra note 16.

The concept of well-being is much broader than physical health; it refers to a general quality of life. including the availability of a favourable social environment.

Underlying this definition is the recognition that health is a collective social good, that health and wellbeing are often intimately linked and that their determinauts are similar. Colin, supra note 2 at 187-88. Act, stupra note 16, ss. 1-5.

See for example, Learning From SARS, supra note I; Campbell Repori, supra note 3; Second Interim Campbell Report, supra note 3: Canadian Institutes of Health Research. Institute of Population and Public Health, The Fusure of Public Healih in Canada: Developing a Public Heallh. System for the 2/st Century (Ottawa: Canadian Institutes of Health Research. 2003) at 4: Derek Wanless, Securing Good Health for the Whole Population: Final Report (London: Her Majesty's Stationery Office, 2004); U.S., Institute of Medicine, Committee on Assuring the Health of the Public in the 21 st Century, The future of the Public's Health in the 2/st Century' (Washington, D.C.: National Academies Press. 2002): Laurent Chambaud, "Les propositions de la SFSP: La santé publique en France" (2004) 17 Santc publique 617 . 
dissemination to persons who undertake prevention and control activities. Surveillance is considered to have a vital role in the control and prevention of infectious diseases by, for example, detecting outbreaks and then triggering the elements of investigation. It is also used for investigating a range of conditions affecting health such as injuries, chronic diseases and environmental exposures. ${ }^{27}$ In this approach, the surveillance function includes communicable disease reporting, as well as the collection and analysis of data to identify emerging trends or problems.

In contrast, the Quebec Public Health Act separates this traditional surveillance function into two areas of activity: surveillance and health monitoring. The ongoing surveillance of the population's health status refers to the continuous collection and analysis of information about the population in general regarding elements such as demographic, socio-cultural and socio-economic conditions; physical environment; lifestyle, risk factors and prevention habits; general health status; physical and mental health; and available health care services. ${ }^{28}$ Its goal is to assess the health status of the population, observe variations and tendencies, detect emerging problems, gather data about the determinants of health and identify priorities. ${ }^{29}$ The ultimate purpose of this ongoing surveillance is to inform decision makers as well as the public. Thus adequately informed, decision makers are better equipped to make decisions, develop policies, plan and evaluate programs, implement services for the population and involve interveners from other sectors whose activities have an impact on population health and well-being. Similarly, an informed public can take action to improve its health and can provide feedback to public health authorities with regard to its needs. ${ }^{30}$ This is distinguished from public health monitoring, an activity that is part of the health protection function. Though public health monitoring also involves the ongoing collection of data, it targets persons who are at risk of contracting, or are affected by, an infectious disease or other threat to health. The collection of data is also more direct than in the case of surveillance, and stems from the authority that public health actors have to intervene in order to protect public health. ${ }^{31}$ In concrete terms, the mandatory reporting of infectious diseases and other threats to health, the collection of information through public health investigations and the treatment of that information constitute public health monitoring rather than surveillance pursuant to the Public Health Act.

\section{B. Public Healti SuRveillance Plans and Data Collection}

In order to address the evolving needs of public health, the $A \mathrm{c}$ expands the mandates of existing public health actors and equips them with the tools necessary to fulfil their new roles. Among these is the responsibility to develop surveillance plans. The Minister and the public health directors (provincial and regional) must develop plans for the surveillance of the

: Verla S. Neslund, Riclaard A. Goodnan \& David W. Fleming. "Fronlline Public Health: Surveillance and Outbreak Investigations." in Richard A. Goodman et al. eds . Lan' in Public Health Prachice (New York: Oxford University Press. 2003) 143 at 147.

2x Lynda Bouthillier \& France Filiatrault. Repires pour une réfexion éthuque en surveillance contunue de l'śtar de santé de la population (Montreal: Secrétariat du Comité d'éthique de la santé publique, 2003) at 9 [Bouthillier \& Filiatrault, Repires]; J.D. 27 November 2001, supra note 18 at 9-10. Act, supra note 16, s. 33 .

Bouthillier \& Filiatrault, Repères, supra note 28 at 6; J.D. 27 November 2001, supra note 18 at 9-10. Bouthillier \& Filiatrault. Reperes, ibid. at II. 
health status of the populations they serve. These plans must set out "the purpose and object of the surveillance, the personal or non-personal information it will be necessary to collect, the proposed sources of information, and the analytic study necessary to be able to exercise their surveillance function." 32

The mandate to conduct surveillance is accompanied by the authority to collect information, including personal information, from various sources. First, the $A c t$ authorizes the use, for surveillance, of information initially collected for other purposes. The Minister and the public health directors can therefore require physicians, medical laboratories, health and social services institutions, government departments and other bodies to provide information they have in their possession. The only limitation imposed is that the information must be necessary for the implementation of a surveillance plan. ${ }^{33}$ Second, the Minister must establish and maintain, for the purpose of ongoing surveillance, systems for the collection of data regarding births, stillbirths and deaths, as well as the prevalence, incidence and distribution of health problems that have a significant impact on mortality, morbidity and disability. ${ }^{34}$ These data are then stored in clinical administrative databanks within the health care system. ${ }^{3 "}$ In addition, the Minister and the public health directors have the authority to conduct periodic surveys on health and social issues that affect population health and wellbeing. ${ }^{36}$ These mechanisms enable public health authorities to collect information that other data collection systems are not designed to (for example, about lifestyle), or to link together information about factors such as lifestyle, diseases, use of health and social services and socio-demographic variables. ${ }^{37}$ For example, a longitudinal survey is being conducted in the Saguenay-Lac-St-Jean region to gather information about the lives of youth and to measure the importance of family, school and psychosocial environments on academic performance and social adaptation. ${ }^{38}$ Another survey is under way to obtain a picture of the health of the Inuit of Nunavik. It includes the distribution of questionnaires about health and social environment, the measurement of biometric factors and the collection of blood samples for analysis. ${ }^{39}$ It should also be noted that the collection, use and disclosure of personal information pursuant to the Public Health $\mathrm{Act}$, including for purposes of surveillance and

Act, supra note 16, s. 35. In practice, the authorities mandated to conduct health surveillance in the province (i.e. the Minister, the National Public Health Director and the regional public health ditectors) have jointly adopted a common surveillance plan for the years 2004-2007. This will form the common basis of their activities. See Comite d'ethique de santé publique. Avis du Comité d'èthique de santi publique : Projet de Plan commun de sunveillance de l'star de sume de la population et de ses décerminants 2004-2007 (Montréal: Secrélarint du Comité d'élhique de santé publique, 2004) at 3 [Plan commun].

$A c t$, ibid., s. 38. The information cannot identify the person to whom it relates or enable him or her to be identified, but must enable information to be obtained for each area, municipality. borough or ward. Ibid., ss. 44,47

Bouthillier \& Filiatrault, Reperes, supra note 28 at 7.

Act, supra note 16. ss. 39-40. While province-wide surveys must be conducted by the Institut de la statistique du Quchec, other surveys may be realized by the Minisler. by another organization or by a public health director (s. 42 ). Bouthillier \& Filiatrault. Repères. supra note 28 at 7.

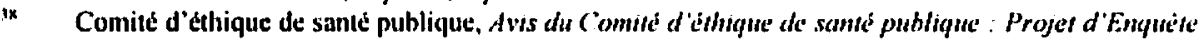
longitudinale auprès des élèves saguenéens ef jeamois agés de / f ans en 20122(Montréal: Sccrétariat du Comilé d'éthique de Santé publique, 2004).

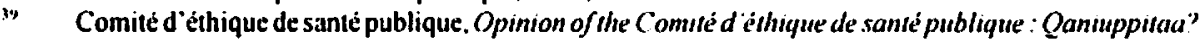
Hovr are we? Proposed Health Suniey of the imuit of Nunavik - 200t (Montrèal: Secretariat du Comite d'cthique de Santé publique, 2004) [Qaniuppitaa? How' are we?]. 
monitoring, is also subject to Quebec's privacy legislation. ${ }^{20}$ Pursuant to An Act Respecting Access to Documents Held by Public Bodies and the Protection of Personal Information, plans for proposed surveillance activities and collection of personal information must be submitted to the Commission d'accès a l'information for its review and approval prior to implementation. ${ }^{41}$ The legislative scheme therefore creates a mechanism that balances the power of public health authorities to collect information with the public's and individuals' interests in the protection of privacy.

\section{The Creation of the Comité d'éthique de Santé Publique}

Early in the development of the Public Health Act, it became obvious that the core public health functions, and the public health interventions implemented to carry out these functions, raised a number of ethical issues. A forum was needed for the discussion of the ethical aspects of proposed interventions, the values that these interventions were based upon and the values of the target population. No organized structure existed to conduct an ethics review of public health activities such as that which existed for research and some clinical interventions. ${ }^{42}$

Additional concerns were identified with respect to the protection of personal information. Public health interventions often required access to personal information; for example in surveillance activities, in order to draw a portrait of the health status of the population; and in the mandatory reporting of infectious diseases, for the purpose of health protection. Given the sensitivity of the information requested and the significance currently attached to individual rights and personal privacy, the requests of the public health sector were sometimes viewed with scepticism. Moreover, surveillance activities were often perceived as research activities. There was, therefore, a need to reassure regulatory instances, such as the Commission d'accès a l'information, as well as the public, of the social value and the scientific validity of these activities. This could be accomplished by encouraging the development of an ethical perspective for public health, thus improving its practice. ${ }^{43}$

The CESP was created to address these needs. It enables the Minister of Health and Social Services and the public health directors to submit planned public health activities to an ethics review process, thereby addressing concerns with regard to potential invasions of privacy, infringements of individual freedoms or impact on social values such as equity and solidarity. ${ }^{\text {th }}$ This ensures a level of transparency with regard to the use of personal information, which in turn contributes to building public confidence in the process and in the

Civil Code of Quebec, supra note 19, art. 35-41; An Act respecting Access to Documents Held by Public Bodies and the Protection of Personal Information, R.S.Q., c. A-2.1: An Act respecting the Prosection of Personal Information in the Private Sector, R.S.Q. c. P.39.1: An Act respecting Health Services and Social Services, R.S.Q. c. S-4.2, ss. 17-28.

$1 \quad$ lbid. ss. 76, 122-24.

12 J.D. 18 September 2001, supra note 18 at 3; France Filiatrault, Présentation et règlement de fonctionnement interne du Comité d'éthique de santé publique (Montreal: Secrétariat du Comité d'éthique de santé publique, 2003) at 5 .

$4 \quad$ Filiatrault, Bbid.; J.D. 18 September 2001, ibid. at 48-52 (Mme. Pauline Champoux-Lesage); J.D. 27 November 2001, supra 18 at $9 \cdot 10$ (M. Richard Masse). 
credibility of public health authorities. ${ }^{45}$ Though its activities are circumscribed, the CESP is a good example of a non-political forum in which public health interventions and activities can be examined in light of the broader goals of public health. In providing a transparent procedure, such organizations can pave the way for factors that contribute to public trust such as accountability, reliability, reciprocity and communication. ${ }^{46}$

\section{THE MANDATE OF THE COMITE D'ÉTHIQUE dE SANTÉ PUBLIQUE}

The role of the CESP is to advise, and to make recommendations to, the Minister of Health and Social Services and the public health directors on the ethical aspects of public health activities. Its specific mandate, as prescribed by the Public Health Act, is twofold:

(1) to evaluate all surveillance plans and proposed surveys of health and social issues submitted by the Minister or the public health directors and provide its opinion on the ethical aspects of these plans and surveys; as well as

(2) to give its opinion, at the Minister's or the National Public Health Director's ${ }^{47}$ request, on ethical issues arising out of the application of the Public Health Act such as the activities planned in the national public health program or in regional or local public health action plans. ${ }^{48}$

The main function of the CESP is to provide advice on public health surveillance activities. ${ }^{49}$ All proposed surveys of health and social issues and surveillance plans prepared by the Minister and the public health directors must be submitted to the CESP for review prior to their implementation. ${ }^{\text {so }}$ Given that the requirement for public health authorities to develop surveillance plans and surveys is a new obligation created by the $A c t$ in 2002, and that the first plans came into being shortly thereafter, these have occupied most of the Committee's agenda since its creation. 'Its activities are not limited to surveillance, however. The CESP may address issues stemming from other public health functions (health protection, disease prevention or the promotion of health and well-being) if the Minister or the National Public Health Director calls upon the Committee to provide an opinion. It seems that no such requests have been put forward thus far.

Bouthillier \& Filiatrault, Repères, supra note 28 at 5.

See Public Heallh Code of Ethics, supra note 10 for a discussion of these factors.

Though the mandate to address questions submitted by the National Public Health Director is not provided for under the $A c t$, the Minister has stated that the Director's requests are to be considered in the same manner as the Minister's requests. See Comité d'éthique de santé publique, Qui sommes-nous? (2003), online: Comite d ethique de santé publique <www.msss.gouv.qc.ca/sujets/santepub/cesp.html> [Qul sommes-nous?].

Act, supra note 16, ss. 20-21.

Ibid., s. 20. For a discussion of the CESP's mandate, see J.D. 27 November 200I, supra note 18 at 47. 49.

Act, ibid., ss. 36, 43.

Interview of France filiatrault (January 2005) [Filiatrault interview]. Though the Act was adopted in December 2001, the provisions regarding the development of surveillance plans came into force in April 2002. 
The CESP's mandate does not include the review of public health research protocols; these remain under the purview of research ethics boards. ${ }^{52}$ Since the distinction among research, surveillance and surveys is often difficult to make, ${ }^{53}$ one of the challenges for the Committee is to determine whether projects submitted to it fall within the scope of its mandate. The Public Health $\mathrm{Act}$ provides some guidance for distinguishing among research, surveillance, monitoring and program evaluation. Public health professionals involved in the application of the $A c t$ are also developing parameters, but do not have a fixed list of criteria at their disposition. Like the U.S. Centers for Disease Control, ${ }^{54}$ the CESP principally examines the aim of a project in order to decide on its admissibility, i.e. whether it constitutes research or public health practice. ${ }^{\text {ss }}$ The purpose of health surveillance activities is the ongoing assessment of the population's state of health and its determinants. Program evaluation aims to document and evaluate the correspondence between a specific planned program and what was implemented. On the other hand, the ultimate purpose of research is to study a problem, to verify a hypothesis or to develop generalizeable knowledge. In addition, the continuous character of data collection and analysis is an essential element of surveillance, while in the context of research, these activities are generally of limited duration. ${ }^{36}$ As one of the tools of surveillance, surveys are more difficult to classify, since they can use the same methodology as research. They are also conducted over predetermined, limited periods of time. Complicating matters is the fact that many interventions have a dual purpose. A surveillance plan or a proposed survey, for example, may contain a research component, either because it is part of a formal research protocol or simply because it aims to produce generalizable knowledge. ${ }^{37}$ In such cases, projects are analyzed by the CESP but must also undergo ethics review by a research ethics board. It is clear that the

32 Filiatrault, supra note $\mathbf{4 2}$ at 6.

3. Jean Joly, "Recherche et non-recherche en santé publique ou qui gouverne quoi" in Michael McDonald, ed., Gowvernance de la recherche en sanié avec des sujels humains (RSSH) (Ottawa: Law Commission of Canada, 2000) 167 at 172-75. See also Kathleen M. MacQueen \& James W. Butehler, "Ethics, Practice, and Research in Public Health" (2004) 94 American Journal of Public Health 928. See U.S., Department of Health and Human Services, Centers for Disease Control and Prevention, Office of the Chief Science Officer, Guidelines for Defining Public Health Research and Public Health Non-Research (1999), online: Centers for Disease Control and Prevention <www.cdc.gov/od/ads/ opspoll1.htm>.

ss It is not clear that the CESP has the mandatc to determine whether a project constitutes research or surveillance. It can be argued that persons submitting projects to the CESP have the responsibility to show that their project falls within the CESP's mandate. Nonetheless, since the committee must evaluate the admissibility of submitted projects to its own review process, it in effect determines whether, in the opinion of its members, the proposed project constitutes research or not, or contains elements of surveillance. Filiatrault interview, supra note 51

It can be argued that the determination of the nature of a public health activity based on its aim leaves the decision whether a project constitutes research to the practitioners who have an interest in its outcome. Interventions that are based on identical procedures and methods would require or not, the approval of a research ethics board based solely on the stated intent. In the alternative, interventions could be characterized by considering the level of risk they present. Projects that present more than minimal risk would constitute research, while those that are low risk would be considered surveillance and not be subject to the requirement of obtaining prior approval. This would create complications, particularly in situations where health protection requires immediate action. See Joly, supra note 53. Information provided by France Filiatrault. See also Amy L. Fairchild \& Ronald Bayer, "Ethics and the Conduct of Public Health Surveillance" (2004) 303 Science 631 at 631-32.

For example, the proposed Qaniuppitaa? How are we? survey of the Inuit people was also part of a circumpolar cohor study of individuals living in Nordic regions and involving researchers from various countries (supra note 39). The survey was therefore reviewed by the CESP and again by a research ethics board, separately. 
classification of some projects will carry some ambiguity. The Committee recognizes that it will have to decide these on a case-by-case basis, while ensuring that its decisions appear coherent to observers. ${ }^{38}$

The CESP is not a decisional body. Unlike research ethics boards, its approval is not required in order for a surveillance plan or proposed survey to be carried out. This does not entail, however, that the Committee has no authority. It may not have the legal power to compel actions, but its role, its independence, ${ }^{99}$ the public nature of its opinions and the expertise of its members give the Committee moral authority.

The mandate of the CESP is therefore limited. As an advisory committee, its role consists of providing an opinion as mandated. The CESP does not have the authority to comment, of its own initiative, on an aspect of the national public health program, a public health action plan or a public health intervention. For example, unless the Minister or the National Public Health Director decided to request its advice, the CESP could not publish an opinion on the government's strategy to prevent the spread of West Nile Virus in the province, the provincial smoking cessation campaign, or plans for the control of communicable disease outbreaks such as a SARS outbreak if it occurred in Quebec. The Committee cannot receive requests for opinions from community organizations or citizen groups. Moreover, regional public health directors who may have ethical queries about an intervention cannot address the Committee directly. They can present their request to the National Public Health Director who may then communicate with the CESP.

Because the CESP was a novel creation, the $A c t$ 's drafters deemed it would be prudent to circumscribe its mandate. This would ensure that the Committee would not be inundated with various requests during its first years, when it would need to develop internal regulations and procedures. A more focused mandate would also give the Committee the opportunity to develop an expertise in a particular area. ${ }^{60}$ The choice was made to focus the Committee's work on ethical aspects of ongoing health surveillance since the most pressing ethical issues in public health seemed to stem from that function. ${ }^{61}$ However, as the CESP moves forward in its work, it is developing a common approach in its activities, a legitimacy and valuable expertise that would enable it to address a variety of ethical issues that are not currently within the scope of its mandate. ${ }^{62}$ A number of areas of public health intervention raise ethical dilemmas, but if they are outside the terms of reference of the CESP, they do not undergo ethics review. For example, considerable powers are given to public health authorities to protect public health: the authority to compel medical examinations, treatment, isolation or quarantine; the power to enter places and seize objects in order to conduct investigations; the power to close down buildings or businesses; and the authority to compel the disclosure of personal information about individuals. ${ }^{63}$ Though these powers are justified in light of the public interest in the protection of population health, they conflict with equally

Interviews of France Filiatrault and Daniel Weinstock (January 2005).

The Committec, though receiving administrative support from the Ministry of Health and Social Services, is morally independent. See Section IV above.

Interview of Richard Masse (November 2004).

J.D. 27 November 2001, supra note 18 at II-17, 49-50.

Interview of Daniel Weinstock (January 2005) [Weinstock interview].

Act, supra note 16, ss. 83, 86-88, 100 . 
valuable social interests in the protection of personal privacy and integrity. As discussed above, the CESP does not have the mandate to comment on these interventions unless invited to do so by the Minister or the National Public Health Director. The SARS outbreak that affected other jurisdictions provided the opportunity to examine the ethics of the province's health protection policies and programs before a critical or emergency situation occurs. While this could have conferred increased political legitimacy upon the actions of public health authorities and potentially improved practice, the CESP was not invited to do so. A broader mandate could empower the committee to address such issues of its own volition, thus ensuring that ethically sensitive activities and interventions are prospectively examined, that ethical aspects are addressed, and that they are perceived as justifiable.

\section{Organization of the Comité D'ÉthiQue de SANTÉ PUblique}

The CESP follows a participatory model. As provided by the Public Health Act, its members include members of the public as well as experts. The Committee is composed of the following members who are appointed by the government:

an ethicist;

three representatives of the population who have no professional ties with the health and social services system (current members include one lawyer and two former teachers);

a public health director from one of the province's regions; and

two professionals working in the public health sector, one of whom is involved in ongoing public health surveillance."s

The government may also appoint two additional members to the CESP if it considers that their expertise would be relevant to the committee. ${ }^{66}$ No such members seem to have been appointed at this time. The Committee members elect the Committee's president and vicepresident. $^{67}$

In addition, an individual is named by the National Public Health Director to act as the Committee's secretary. This person attends meetings and has the right to be heard, but not the right to vote. ${ }^{68}$ Employed by the Ministry of Health and Social Services, the secretary performs administrative tasks for the Committee, including the recruitment of members for nomination by the government; the coordination of Committee meetings; the drafting of

The term "ethicist" is not defined in the $A c t$. Given that there is no consensus on the definition of such a profession (even among those who specialize in ethics or bioethics), this provision has been criticized for its lack of precision. See for example, College des medecins du Quebec, Mémoine du College des médecins du Quèbec : Projes de loi ñ 36. "Loi sur la santé publique" (2001) at 6, online: Collège des médecins du Québec <www.cmq.org/UploadedFiles/mprojloi36santepublique.pdßs. Act, supra note 16, s. 23.

Ibid.

Ibid., s. 26.

Ibid., ss. 24, 27. 
Committee documents, such as minutes, annual reports and summaries of opinions; liaison with various institutions; development of procedures for the submission of plans or projects to the Committee; and reception and follow-up of requests addressed to the Committee. ${ }^{69}$

The CESP therefore includes three members who are experts in public health, three members who, though interested in public health, have no ties to the health care system and one member who may or may not have such ties. ${ }^{70}$ The fact that the CESP includes representatives from different walks of life is a considerable advantage - it provides the Committee with a more complete perspective of public health and the ethical issues that it must address. The participation of individuals who practice in public health is essential to the Committee's work since they bring an intimate knowledge of the field and the issues that arise in the planning and implementation of public health interventions. The presence of representatives of the public is also an important feature. These members bring a different perspective and may raise questions or bring up elements that the experts may sometimes overlook or take for granted."

At an organizational level, although the members of the CESP are appointed by the government, the Committee is an independent entity. In order to ensure a measure of independence from the Ministry of Health and Social Services, the members are chosen after consultations with representatives from sectors and organizations who have an interest in public health. ${ }^{22}$ The independence of the members is essential to the CESP's moral authority and its legitimacy in the eyes of the public. Nonetheless, the CESP has administrative ties to the Ministry of Health and Social Services. The Public Heallh Act provides that the Ministry must supply the administrative support necessary for the Committee to fulfill its mandate. ${ }^{\text {.3 }}$ To this end, a secretariat of the CESP was created within the Direction génerrale de santé publique of the Ministry. It employs the Committee's secretary, a research and socioeconomic planning associate, as well as an administrative assistant, who support the Committee in its tasks. ${ }^{74}$ The Ministry also provides funds for expert consultation fees when

6.) Filiatrault, supra note 42 at 17 (Annexe 2).

31" The ethicist who is currently the president of the CESP does not have any other ties with the health care system.

"Weinstock interview, supra note 62. The composition of the Committee was the object of much discussion during the consultation process that preceded the adoption of the $\mathrm{ACl}$. A number of interveners commented on that issue, arguing for representation of professionals from different fields. See for example, Collège des médecins du Québec, supra note 64 at 6; Féderation des médecins spécialistes du Québec, Mémoire de la Fèdération des médecins spécialistes du Québec. Projel de loi $n^{\circ} 36$ "Loi sur la santé publique " (2001) at 7: Institut national de la santé publique, Mémoire présemté à la Commission des affaires sociales par l'Institu national de santé publigue du Québec. Projet de loi n" 36: Loi sur la santé publique (30 August 2001) at 5; Ordre des inlirmières et infirmiers du Québec, Mémoire. Projet de loi n" 36: Loi sur la santé publique (September 2001) at 7

Act, supra note 16, s. 23. The independence of the Committee and the appointment mechanism were the subject of numerous discussions during the consultation process lead ing to the adoption of the $A c t$. Interveners argued that the Committee needed to be independent from the Ministry of Ilealth in order to have legitimacy. It was important that it not be an arm of the Ministry. nor perceived as such. Set Québec, Commission permanente des affaires sociales, Journal des débats 37:26-28 (18-20 September 2001). 
these are required by the Committee, as well as for the members' fees and allowances." Nonetheless, the members of the CESP are not employed by the Ministry.

\section{THE APPROACH OF THE COMITÉ D'ÉtHIQUE DE SANTÉ PUBLIQUE,}

Pursuant to the Public Health Act, when evaluating a surveillance plan or proposed survey, the CESP may give its opinion on elements such as the object of ongoing surveillance, the selected health indicators and health determinants, the type of information to be collected, the sources of information to be used and the proposed analysis. ${ }^{76}$ The Committee is not limited to these elements, however, and can comment on all the ethical issues it deems relevant. It has analyzed a number of additional ethical issues in its opinions, including the appropriateness of consent procedures, the potential risks and benefits of the project for the participants, the provision of support services for participants who need them, the protection of privacy and confidentiality and the concept of health promoted by the project. These analyses are informed by the basic values and principles of public health ethics: beneficence, non-maleficence, autonomy, responsibility, solidarity, respect for privacy and confidentiality, ${ }^{77}$ protection of vulnerable persons and groups and justice. In order to move beyond purely theoretical considerations, the analyses are also based on a thorough understanding of the projects' parameters and the context in which each is to be implemented. ${ }^{78}$

The CESP has therefore adopted an approach based on collaboration and support. The Committee does not view public health ethics as an exclusive field of expertise, nor as specialized theoretical knowledge that is separate from practice. Its members have acquired knowledge about specific concepts that facilitate the identification, discussion and evaluation of ethical issues that arise in the context of public health interventions, but such knowledge is also accessible to others. Public health professionals are intuitively aware of the ethical dimensions of their activities and may have concerns about these, though their concerns may not be clearly articulated or explicit. Prior to the creation of the CESP they did not have the resources, time or space to fully address these concerns. The Committee creates that needed time and space, and the concepts to clarify and to address ethical issues in public health interventions. This is done through a continuous dialogue between the Committee and the public health authorities that submit proposed plans and surveys. ${ }^{79}$ The CESP encourages public health authorities to identify the ethical issues raised by their proposed interventions early in the development stages of a plan or survey, and to communicate these to the Committee, thus ensuring that the Committee can work with them to address ethical considerations throughout all steps of the development of public health interventions. It is hoped that eventually, the ethical aspects of public health interventions will be considered

7.

Act, supra note 16, s. 30.

bid.. s. 20.

Though the CESP does address issues of privacy and confidentiality, an explicit legal framework governs these issues. The Commission d'aeces a l'information also has jurisdiction over the creation of personal files and the collection of personal information by public organizations in the province. The CESP is therefore careful not to impinge on the Commission's jurisdiction.

Plan commun, supra note 32 at 5 .

A distinction is drawn between this approach and the procedure usually followed for research ethics review. where researchers develop their protocols without any input from research ethics boards, and then submit final versions to these boards for their approval. 
as important as their scientific aspects and that this will lead to improved public health practices. In parallel, the CESP's work may lead to the development of more refined and nuanced tools of ethical analysis. ${ }^{80}$

The Committee will generally conclude its opinions with recommendations that may suggest concrete actions or make more open-ended suggestions. An open-ended recommendation may identify and bring to the attention of the Minister or public health director the ethical issues raised by a proposed action or element of a public health program or action plan that require attention. Other recommendations are more specific, suggesting possible solutions to specific ethical issues. In developing these recommendations, the Committee will consider the potential social consequences of the proposed action or plan, seek to find a balance between the values of common good, respect for autonomy and justice and justify the selected options in light of the objectives of the project or plan. ${ }^{81}$

\section{Is a Pubi.ic Heal.ti Ethics Committee Necessary?}

The experience of the Comité d'éthique de santé publique in Quebec, though limited, has been positive. Thus far, its work with public health authorities has raised awareness about the ethical aspects of public health interventions, and has contributed to ensuring that these issues were appropriately addressed in order to improve the practice of surveillance. ${ }^{82}$ As the legal framework for the Public Health Agency of Canada (the Agency) is being developed, the question may be raised whether the Agency needs a mechanism to address the ethical issues that will derive from its policies, programs and interventions. Would the creation of a public health ethics committee, such as the CESP, be beneficial to the Agency?

According to the Public Health Agency of Canada, it will "play a major role in a Canadian network of expertise and research in public health." 83 Its mandate will include:

- coordinating federal efforts in identifying and reducing public health risks and threats;

supporting national readiness to respond to health crises;

acting as a hub for health surveillance, threat identification and disease prevention and control programs;

with other government departments and agencies, developing long-term strategies for infectious disease, chronic disease and injury prevention, emergency planning. as well as preparedness and response to national public health emergencies; and éthique pour le Comité d"cthique de santé publique?: su structure, sa portée" (Montréal: Secrétariat du Comité d'éthique de santé publique. 2003) [Bouthillier \& Filialsault, "Qu" "est-ce qu "un avis ćthiquec"] Bouthillier \& Filiatrault, "Qu'est-ce qu' un avis éthique," ibid. at 6.

Weinstock interview, supra note 62.

Public Health Agency of Cunada. News Release. "The P'ublic Health Agency of Canada" (September 2004), online: Public Health Agency of Canada <mww.phac-aspc.gc.ca/media/nr-rp/2004/phac_c html>. 
on the international stage, sharing Canada's expertise, applying international research and development to Canadian public health programs and policies, and taking a leadership role with global partners. ${ }^{34}$

The Agency will therefore work with the provinces to develop public health policies, programs and interventions aimed at health emergency prevention and response, chronic disease and injury prevention and health promotion." It is inevitable that various ethical concerns will arise in this context. The Agency will need a mechanism to analyze and evaluate ethical aspects of its activities. An open and transparent procedure that would create a non-political space for the discussion of public health goals and activities and population needs would contribute to public trust in the enterprise and, ultimately, to the effectiveness of its programs. Though Health Canada has a Research Ethics Committee, this may not constitute an appropriate vehicle to address these concerns. The values and guidelines governing research and clinical practice, based as they are on the protection of individuals, are not adapted to the public health arena where the focus is on values of community and solidarity. ${ }^{86}$ A committee or a mechanism specifically created to address the ethical aspects of the Agency's non-research activities could ensure that fundamental public health ethics issues are carefully considered, thus fostering a more coherent and nuanced approach to public health. For example, in the initial planning and implementation stages of the Agency, a common approach could be developed with regard to foundational concepts and values such as:

- the tension between collective interests in communal welfare and individual rights to privacy and liberty;

- the role of public health authoritics: whether it is to ensure a certain measure of control over the behaviour of individuals (for example, by compelling cyclists to wear helmets), or rather to inform the population so that individuals are better equipped to make their own health decisions:

the definition or the concept of health that the Agency wants to foster - there are a variety of conceptions of health and of what constitutes a health problem, each reflecting particular values;

- the need for the creation of a dialogue between public health experts, communities and lay persons regarding public health interventions: their justification, their necessity, their appropriateness;

- the protection of vulnerable persons - public health interventions often affect vulnerable persons disproportionately, and it is important not to further stigmatize them through public health interventions; and

*s These are the three public health functions identified by the Public llealth Agency. See Public Health Agency of Canada, "Frequently Asked Questions," online: Public Healih Agency of Canada <www.phac-aspc.gc.ca/media/nr-sp/2004/faq_e.html>.

w/. Fairchild \& Bayer, supra note 56 at 632. 
- the need to consider cultural dimensions in public health interventions.

Such a process, particularly if it is transparent, will build the public's confidence in public health authorities and confer political legitimacy on the public health activities of the Agency and the federal government. As Amy Fairchild and Ronald Bayer suggest with reference to surveillance and monitoring, the ethical oversight of public health activities

can serve as a means of avoiding inadvertent breaches in confidentiality and stigma: it can help ensure that the public understands that surveillance [and monitoring] will occur and what purpose it serves; it can protect politically sensitive surveillance [and monitoring] efforts. There is, after all, an ethical mandate to undertake surveillance that enhances the well-being of populations.

\section{Conclusion}

The Public Health Agency of Canada is poised to become a foundational element of the modernized, "strong and responsive" ${ }^{88}$ public health system that is being developed for Canada. In order to fulfill its leadership role in the management of public health in Canada, it is expected that the Agency will have "appropriate advisory structures to provide for ongoing and timely expert advice from the medical, health and scientific communities, from community and advocacy groups, and from other related sectors. ${ }^{\text {"89 }}$ Ideally, these structures should include mechanisms to adequately address the ethical issues that will arise from the Agency's policies, programs and interventions.

Quebec's Comité d'éthique de santé publique is an interesting example of the form that an ethics advisory committee could take. Created in 2003, its role is to advise and make recommendations to the Minister of Health and Social Services and the public health directors of Quebec on the ethical aspects of public health activities. Though its specific mandate is somewhat limited, the CESP has provided valuable support to public health authorities developing surveillance plans and health and social issues surveys, thus contributing to an increased awareness of the ethical aspects of public health practice. Its independence gives the committee moral authority. The transparency of its processes gives its work and the interventions of public health authorities political legitimacy. Moreover, the participation of non-scientist members in the committee provides a more complete perspective of public health and the ethical issues that the committee must address. As the CESP moves forward, it will need to address various organizational issues, such as the need to coordinate its work with that of research ethics boards when projects have a dual aim, and the possibility of expanding its mandate.

Though the jurisdiction of the federal government over public health differs from that of the provinces, the lessons learned from Quebec's experience can potentially be instructive for the Agency. What should an ethics structure look like? It could take the form of an advisory committee. It should be independent from the Agency. Its members should include

\section{" $\quad$ bid.}

xx Carolyn Bennett, "Strengthening the Pan-Canadian Public Health System: Discussion Paper." ontinc: Public Health Agency of Canada <inww.phac-aspc.gc.ca/pdfabout/strengthening.pdi> at i. 
public health professionals, scientists, a person knowledgeable about ethics and lay members who will represent the population. It should be transparent and its opinions and recommendations should be available to the public. Its mandate should extend to all the Agency's public health activities. In the case of interventions that require rapid response, the policies and programs on which these interventions are based should be analyzed by the committce prior to their implementation. It should have the authority to mandate itself to address specific ethical aspects of public health practice. The role of such a public health ethics structure will be instrumental in ensuring that fundamental public health ethical issues are carefully considered and that the public health system that is developed adopts a coherent approach to health surveillance, disease prevention and health protection - one that will be based on commonly accepted values and principles. Building a strong public health system requires no less. 